blind or have no useful degree of sight. The education will be as liberal as in the best public schools for girls, and the physical and mental development afforded will enable blind girls to live full and active lives at school, at home, and in professions. The principal is Miss Phyllis Monk, M.A., formerly of Girton College, Cambridge, and latterly a mistress of Roedean School, Brighton; with her is associated efficient teaching and house staff.

I have visited the College, and can speak of the excellence of the arrangements for teaching and for the comfort of the girls; also on my visit there accompanied me a lady experienced in domestic affairs, and she was greatly impressed with the domestic arrangements and the evident happiness of the resident pupils. The fees for a place of this order are moderate, and there are some scholarships for girls of promise.

There are (happily) not many blind girls of the professional class, but for these few there can be no better place of education and training than this new College. Miss Phyllis Monk, the principal, will be pleased to receive by appointment any ophthalmic surgeon and others interested to view the College and its arrangements. The address is "The Cedars," Chorley Wood, Herts. The College is ten minutes' walk from the station across the heath, and the London road passes within a hundred yards of the lodge gates.

Hariey Street, W.1,

$$
\begin{aligned}
& \text { I am, etc., } \\
& \text { N. BISHOP HARMAN. }
\end{aligned}
$$

November 14, 1921.

\title{
HOLTH'S IRIDENCLEISIS
}

To the Editor of The British Journal of Ophthalmology Sir,-In the December number of the British JourNal of Ophthalmology Professor Holth's note to his paper on Iridencleisis seems to imply that in the "Textbook of Ophthalmic Operations," which he quotes, we had not recognized the basic principles of his methods.

We ask your permission to point out that the description of his operations appears as part of a section on glaucoma, dealing with filtration through a fistula between the anterior chamber and the subconjunctival tissue, kept open by the presence of a fold of iris (pp. 3r0, 3r1), and that under the head of Holth's Operation, we say :-

" Holth attempted to lay down rules to regulate the performance 
of this manoeuvre; he aimed ... at fixing a very small fold of iris under a fold of conjunctiva through an incision just outside the sclero-corneal junction. Sometimes he combined it with an iridectomy, but sometimes no iris was removed. His paper gives so great a variety of methods that it is hardly possible to describe one single plan as 'Holth's Operation.' "'

This full quotation will show that we fully understood the underlying principles of the paper, and we express our regret to Professor Holth, if this did not appear obvious to him.

We are, Sir,

Yours very truly,

Harold Grimsdale,

Harley Place, N.W.1,

ELMORE BREWERTON.

December 28, 1921.

\section{MERCANTILE MARINE VISION TESTS, ETC.}

To the Editor of The British Journal of Ophthalmology

SIR,-In your issue of December Dr. A. Greene asks what action the widowed mother of a cadet should take in order to recover the expense she has been put to in having her son trained on the "Conway" under circumstances he details. I should advise her to take no steps at all, and certainly not to throw good money after bad, but I do advise the young man-if he is keen on going to sea-to try another Steamship Company and yet another, and I venture to say he will be ultimately passed and accepted with flying colours if he sits tight and does not reveal the fact that he has already been refused by one Steamship Company on account of his sight. I should not apply at present, as, on account of the slackness of trade, etc., many vessels are laid up and there is no demand for officers. Every ophthalmic surgeon must have met with parallel cases, one very glaring one happened to myself many years ago, an influential county gentleman consulting me on the following point:- $-\mathrm{He}$ was guardian to a young man and anxious to get him into the Army, but stated to me that the Army authorities had themselves refused him on account of his sight, so he brought him to me to ascertain if they were justified in so doing. Well, I speedily showed him that the sight of his ward's eyes was so bad that they couldn't possibly accept him, and the incident closed.

A few years later this gentleman, consulting me about his own eyes, referring to his ward's case, said, "We got him into the 